\section{Right and wrong feedback in multiple probability learning as a determinant of subsequent performance ${ }^{1}$}

\section{LOWELL M. SCHIPPER, The Pennsylvania State University, University Park, Pa. 16802, and BRUCE KNERR, ${ }^{2}$ University of Maryland, College Park, Md. 20742}

The effect of being right or wrong on a trial in a probability-learning context could influence the decision to try for the long shot or to maximize on the immediately following trial. Instructions in probability-learning situations generally encourage $S s$ to be correct as often as possible. Results showed no evidence for any trend loward maximization on the basis of the rightness or wrongness of the immediately preceding decision.

The purpose of this study was to investigate the effects of rightness and wrongness of a first prediction on a second prediction in a multiple probability-learning situation where each trial required two predictions by $S$. In the usual probability-learning context, first-order sequential effects are analyzed by comparing behavior on Trial $\mathrm{k}$ with that on Trial $k+1$ for all ordered couplets. In the present study, each trial consisted of two related parts such that an ordered couplet was contained within the individual trial. The principle reason for this novel arrangement was to examine more clearly the effects of being right or wrong in a specific situation where the sequential relationship could be more obvious to $S$. Additionally, the arrangement provided a situation where $S$ essentially switched back and forth from one probability-learning problem to another probability-learning problem. horizontal line, respectively, drawn through the corresponding circle on the answer sheet.

\section{Design}

Five experimental treatments and five control treatments were run in small groups, maximum $\mathrm{N}=6$ for any one group. The treatments are shown in Table 1 . In Experimental $\mathrm{T} 1$ through $\mathrm{T} 5$, each of the left and right amber lights followed the green light on $50 \%$ of the trials. In T1, the red light followed each amber light $3 / 14$ of the trials on which that amber light was illuminated. In $\mathrm{T} 2$ and $\mathrm{T} 3$, the proportions of red-after-amber were $7 / 14$ and 11/14, respectively. Proportions of $11 / 14$ and $3 / 14$ for left and right red-after-amber were used for $\mathrm{T} 4$ and the reverse for $\mathrm{T} 5$.

Control Treatments 1 through 5 were the same as experimental treatments, with the exception that only red-after-amber predictions were made.

Each block of training was made up of 28 trials, 14 with each of the amber lights randomly ordered. Total training consisted of 10 blocks, or 280 trials.

\section{RESULTS}

intertrial interval, $S$ again made his predictions from bottom to top, first predicting which amber light would come on, then predicting whether or not the red light would follow whichever amber light did come on.

Control Ss saw only the top two boxes and predicted whether or not the red light would come on following whichever amber light had occurred in the first part of the trial. Time relationships for the amber and red lights and intertrial intervals were the same as for the experimental Ss.

All Ss were instructed to try to be correct in their predictions as often as possible. Responses were made on a specially prepared answer sheet with either four or three circles arranged for each trial in the same position as the display lights. S predicted the occurrence or nonoccurrence of a particular light with a short vertical or

Learning curves for all treatments exhibited nothing peculiar, rising toward $79 \%$ where the experimental and control probabilitis:s of red-after-amber were .786 , declining toward $21 \%$ where the experimental and control probabilities of red-after-amber were .214 , and varying around $50 \%$ for probabilities of .500 in predictions made of the amber lights in the experimental treatments and for red-after-amber predictions in both experimental and control treatments for $\pi=.500$. Only Experimental T5 showed little "learning" of the programmed probabilities.

The data bearing on the original purpose of the experiment are presented in Table 2.

\section{DISPIAY}

Table 1

Probabilities of Occurrences of Left and Right Amber Lights and Conditional Probabilities of the Red Light Following the Occurrence of Each Amber Light

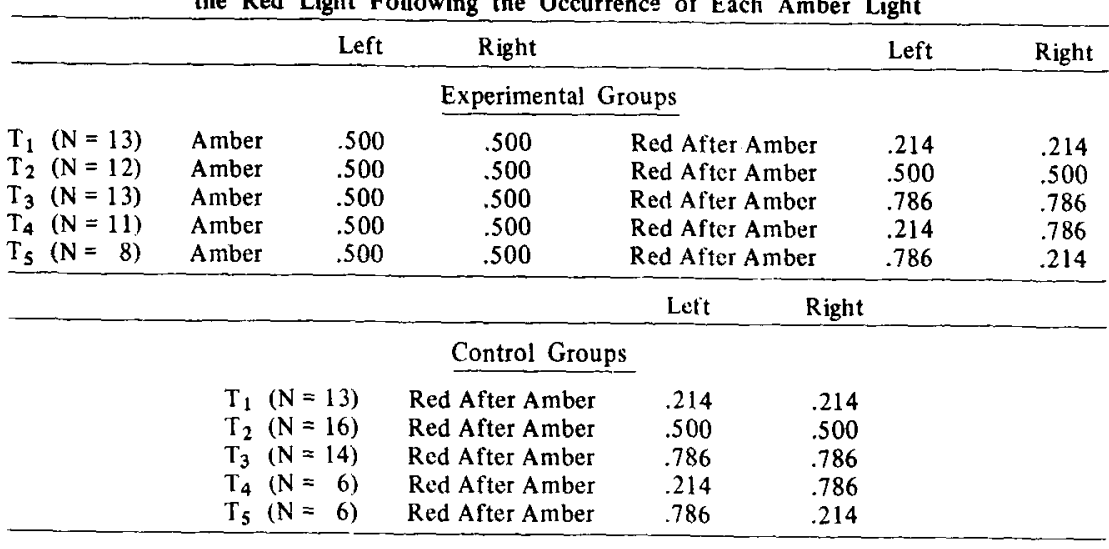

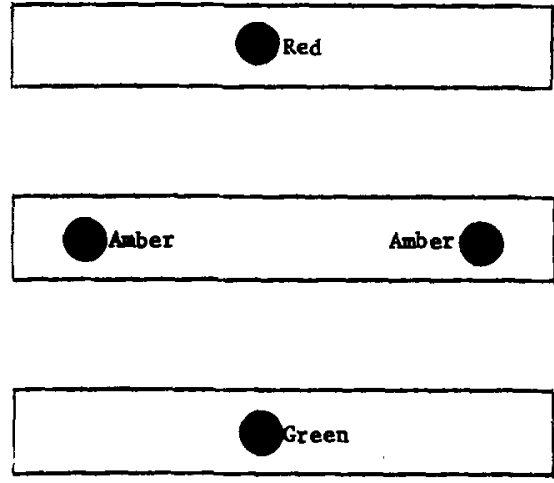

Fig. 1. Display as seen by experimental Ss. Control Ss saw only the top two boxes. 
Table 2

Summary of Correct Second Predictions After Correct and Incorrect First Predictions

\begin{tabular}{|c|c|c|c|c|c|c|c|c|c|c|c|c|c|}
\hline \multirow{2}{*}{\multicolumn{2}{|c|}{$\begin{array}{l}\text { Experimental } \\
\text { Treatments }\end{array}$}} & \multicolumn{10}{|c|}{ Blocks } & \multirow{2}{*}{$\begin{array}{c}\text { Meari } \\
\text { Proportion } \\
\text { Correct } \\
\text { Block: } \\
6-10 \\
\end{array}$} & \multirow{2}{*}{$\begin{array}{l}\text { Expected } \\
\text { Proporion } \\
\text { Correct } \\
\text { Blocks } \\
6-10 \\
\end{array}$} \\
\hline & & 1 & 2 & 3 & 4 & 5 & 6 & 7 & 8 & 9 & 10 & & \\
\hline$T_{1}$ & $\begin{array}{l}C C \\
X C\end{array}$ & $\begin{array}{l}.535 \\
.545\end{array}$ & $\begin{array}{l}.612 \\
.552\end{array}$ & $\begin{array}{l}.571 \\
.648\end{array}$ & $\begin{array}{l}.532 \\
.610\end{array}$ & $\begin{array}{l}.645 \\
.651\end{array}$ & $\begin{array}{l}.620 \\
.653\end{array}$ & $\begin{array}{l}.619 \\
.672\end{array}$ & $\begin{array}{l}.649 \\
.641\end{array}$ & $\begin{array}{l}.725 \\
.668\end{array}$ & $\begin{array}{l}.622 \\
.721\end{array}$ & $\begin{array}{l}.647 \\
.671 \\
.659\end{array}$ & .650 \\
\hline$T_{2}$ & $\begin{array}{l}C C \\
X C\end{array}$ & $\begin{array}{l}.316 \\
.686\end{array}$ & $\begin{array}{l}.377 \\
.742\end{array}$ & $\begin{array}{l}.452 \\
.581\end{array}$ & $\begin{array}{l}.413 \\
.520\end{array}$ & $\begin{array}{l}.564 \\
.522\end{array}$ & $\begin{array}{l}.434 \\
.641\end{array}$ & $\begin{array}{l}.464 \\
.529\end{array}$ & $\begin{array}{l}.540 \\
.535\end{array}$ & $\begin{array}{l}.416 \\
.604\end{array}$ & $\begin{array}{l}.438 \\
.493\end{array}$ & $\begin{array}{l}.458 \\
.559 \\
.503\end{array}$ & .500 \\
\hline$T_{3}$ & $\begin{array}{l}\mathrm{CC} \\
\mathrm{XC}\end{array}$ & $\begin{array}{l}.578 \\
.487\end{array}$ & $\begin{array}{l}.653 \\
.598\end{array}$ & $\begin{array}{l}.632 \\
.598\end{array}$ & $\begin{array}{l}.623 \\
.567\end{array}$ & $\begin{array}{l}.681 \\
.616\end{array}$ & $\begin{array}{l}.679 \\
.602\end{array}$ & $\begin{array}{l}.680 \\
.676\end{array}$ & $\begin{array}{l}.743 \\
.662\end{array}$ & $\begin{array}{l}.666 \\
.629\end{array}$ & $\begin{array}{l}.696 \\
.682\end{array}$ & $\begin{array}{l}.694 \\
.649 \\
.672\end{array}$ & .668 \\
\hline $\mathrm{T}_{4}$ & $\begin{array}{l}\mathrm{CC} \\
\mathrm{XC}\end{array}$ & $\begin{array}{l}.518 \\
.491\end{array}$ & $\begin{array}{l}.573 \\
.666\end{array}$ & $\begin{array}{l}.661 \\
.548\end{array}$ & $\begin{array}{l}.697 \\
.647\end{array}$ & $\begin{array}{l}.674 \\
.639\end{array}$ & $\begin{array}{l}.685 \\
.625\end{array}$ & $\begin{array}{l}.706 \\
.709\end{array}$ & $\begin{array}{l}.648 \\
.621\end{array}$ & $\begin{array}{l}.692 \\
.645\end{array}$ & $\begin{array}{l}.662 \\
.681\end{array}$ & $\begin{array}{l}.678 \\
.656 \\
.668\end{array}$ & .667 \\
\hline $\mathrm{I}_{5}$ & $\begin{array}{l}\mathrm{CC} \\
\mathrm{XC}\end{array}$ & $\begin{array}{l}.508 \\
.558\end{array}$ & $\begin{array}{l}.504 \\
.548\end{array}$ & $\begin{array}{l}.462 \\
.508\end{array}$ & $\begin{array}{l}.509 \\
.606\end{array}$ & $\begin{array}{l}.416 \\
.508\end{array}$ & $\begin{array}{l}.559 \\
.484\end{array}$ & $\begin{array}{l}.528 \\
.541\end{array}$ & $\begin{array}{l}.460 \\
.571\end{array}$ & $\begin{array}{l}.610 \\
.566\end{array}$ & $\begin{array}{l}.504 \\
.514\end{array}$ & $\begin{array}{l}.531 \\
.536 \\
.533\end{array}$ & .545 \\
\hline $\begin{array}{l}\text { Control } \\
\text { Treatments }\end{array}$ & & & & & & & & & & $\begin{array}{r}\mathrm{Ov}_{\mathrm{v}} \\
\mathrm{O} \\
\text { rall } \mathrm{Co}\end{array}$ & $\begin{array}{l}11 \mathrm{CC} \\
1 \mathrm{XC} \\
\text { ined }\end{array}$ & $\begin{array}{l}.607 \\
.620 \\
.613\end{array}$ & .611 \\
\hline $\begin{array}{l}T_{1} \\
T_{2} \\
T_{3} \\
T_{4} \text { and } T_{5}\end{array}$ & & $\begin{array}{l}.571 \\
.482 \\
.469 \\
.502\end{array}$ & $\begin{array}{l}.590 \\
.506 \\
.612 \\
.619\end{array}$ & $\begin{array}{l}.629 \\
.459 \\
.622 \\
.541\end{array}$ & $\begin{array}{l}.626 \\
.500 \\
.627 \\
.562\end{array}$ & $\begin{array}{l}.631 \\
.493 \\
.617 \\
.607\end{array}$ & $\begin{array}{l}.651 \\
.486 \\
.678 \\
.642\end{array}$ & $\begin{array}{l}.579 \\
.495 \\
.663 \\
.589\end{array}$ & $\begin{array}{l}.598 \\
.491 \\
.678 \\
.559\end{array}$ & $\begin{array}{l}.642 \\
.455 \\
.701 \\
.633\end{array}$ & $\begin{array}{l}.626 \\
.522 \\
.655 \\
.619\end{array}$ & $\begin{array}{l}.619 \\
.490 \\
.675 \\
.608\end{array}$ & $\begin{array}{l}.632 \\
.500 \\
.670 \\
.614\end{array}$ \\
\hline & & & & & & & & & & & rerall & .593 & .599 \\
\hline
\end{tabular}

This table shows the proportions of correct predictions of red-after-amber for all treatments (a) after the prediction of which amber light would appear was correct (CC), (b) after the prediction of which amber light would appear was incorrect (XC), and (c) when the only prediction for a particular trial was the red light (Control Treatments 1 through 5). Table 2 also shows average proportions of correct predictions for the last five blocks of trials where the rates of responding have more closely approached stability.

Expected proportions of correct responses were calculated for each treatment by obtaining the proportions of red-after-amber predictions made by Ss (p), the proportions of predictions that red would not follow amber $(1-p)$, multiplying these proportions by the actual programmed proportions of occurrences and nonoccurrences of the red light $(\pi)$ and $(1-\pi)$ and summing the respective products $\mathrm{p} \pi$ and $(1-\mathrm{p})(1-\pi)$ (Grant, Hake, \& Hornseth, 1951; Schipper, 1956).

$$
\text { DISCUSSION }
$$

That these data exhibit no pathological trends is seen by examining the last two columns of Table 2, where marked deviations between respective pairs would indicate nonrandom or "predictable" occurrence of the red event light.

There seems littie support for the hypothesis that being right or wrong has any effect on the immediately subsequent predictions. Where maximization of correctness of behavior is meaningful (Experimental Treatments 1, 3, 4, and 5), the effect was never more than an increase of correctness of a few per cent. Additional comparisons between experimental and control treatments lead to the same conclusion.

GRANT, D. A., HAKE, H. W., \& HORNSETH, J. P. Acquisition and extinction of a yerbal conditioned response with differing percentages of reinforcement. Journal of Experimental Psychology, 1951, 42, 1-5.

SCHIPPER, L. M. Prediction of critical events in contexts of different numbers of alternative events. Journal of Experimental Psychology, $1956,52,377-380$.

\section{NOTES}

1. This study was supported in part by a grant from the Central Fund for Research of The Pennsylvania State University.

2. Mr. Knerr was an NSF-URP participant (NSF Grant GY-975) at The Pennsylvania State University while assisting in the conduct and analysis of this study. 